\title{
Potential metal-related strategies for prevention and treatment of COVID-19
}

\author{
Ya-Qiong Ni, Hui-Hui Zeng, Xian-Wen Song, Jun Zheng, Hui-Qiong Wu*(i), \\ Chun-Tai Liu, Yi Zhang*(i)
}

Received: 22 April 2021 / Revised: 28 September 2021/Accepted: 10 October 2021 / Published online: 17 January 2022

(C) Youke Publishing Co., Ltd. 2022

\begin{abstract}
The coronavirus disease 2019 (COVID-19) caused by severe acute respiratory syndrome coronavirus 2 (SARS-CoV-2) has posed severe threats to human health, public safety, and the global economy. Metal nutrient elements can directly or indirectly take part in human immune responses, and metal-related drugs have served as antiviral drugs and/or enzyme inhibitors for many years, providing potential solutions to the prevention and treatment of COVID-19. Metal-based drugs are currently under a variety of chemical structures and exhibit wide-range bioactivities, demonstrating irreplaceable advantages in pharmacology. This review is an intention to summarize recent progress in the prevention and treatment strategies against COVID-19 from the perspective of metal pharmacology. The current and potential utilization of metal-based drugs is briefly introduced. Specifically, metallohydrogels that have been shown to present superior antiviral activities are stressed in the paper as potential drugs for the treatment of COVID-19.
\end{abstract}

Y.-Q. Ni, H.-H. Zeng, X.-W. Song, J. Zheng, Y. Zhang*

Hunan Provincial Key Laboratory of Micro and Nano Materials Interface Science, College of Chemistry and Chemical Engineering, Central South University, Changsha 410083, China e-mail: yzhangcsu@csu.edu.cn

H.-Q. Wu*

Hanshan Normal University, Chaozhou 521041, China

e-mail: huiqiong.wu@qq.com

H.-Q. Wu

College of Chemistry and Environmental Engineering, Shenzhen University, Shenzhen 518071, China

C.-T. Liu

Key Laboratory of Materials Processing and Mold (Zhengzhou University), Ministry of Education, Zhengzhou 450002, China
Keywords COVID-19; SARS-CoV-2; Metal-related drugs; Metal nutrient elements; Metallohydrogel

\section{Introduction}

In December 2019, an outbreak of pneumonia caused by a new strain of coronavirus named "severe acute respiratory syndrome coronavirus 2 (SARS-CoV-2)" was firstly reported [1]. Later on, cases of SARS-CoV-2 were found all over the world [1], arising a long-lasting worldwide health crisis. Systemic diseases such as viral pneumonia caused by this virus were named "coronavirus disease 2019 (COVID-19)" [2]. Till September 27, 2021, about 0.23 billion people worldwide had been infected by SARS-CoV2 and its variants, and the cumulative death toll is about 4.7 million [3]. During the COVID-19 pandemic, prompt and firm contributions from worldwide researchers have resulted in many effective treatments. To date, a variety of antiviral drugs (such as nucleoside analogs, Type I interferons, protease inhibitors) [4], anti-inflammatory drugs (such as interferon alfa-2b, tocilizumab) [5], antibodies, corticosteroids, and convalescent plasmas [6] have been recommended toward the treatment of COVID-19, whereas genuinely effective drugs are still under screening [4, 7]. Mounting evidence indicates that the development of effective vaccines is the most promising route to stop the pandemic [7, 8]. Until the end of May 2021, the six-month vaccination worldwide has resulted in strongly curbed spreading of SARS-CoV-2 [9]. However, due to the unevenly distributed vaccine resources $[10,11]$ and the long-term side effects posed by COVID-19 [12-14], there is still an urgent need for drugs to combat this disease in an effective, safe, stable, and reliable way. As potential 
solutions, metals and metal compounds have attracted widespread attention due to their unique pharmacological advantage in efficiency, safety, and stability.

Some metal elements, such as selenium, iron, and copper, are known to interrupt the infectious interaction between the virus and the host, preventing the virus from entering the host and/or alleviating the symptoms [15-18]. Trace metal elements such as zinc, selenium, and magnesium are known to play an important role in regulating the human immune system, and their deficiencies are related to the severity of the symptoms in COVID-19 patients [19-25]. In addition, metal compounds have various chemical structures and exhibit wide-range bioactivities [26]. Metallodrugs are known to play an important role in direct antiviral or inhibiting critical enzymes in the process of virus replication for the SARS-CoV-2 infection [27, 28]. Metallodrugs can also be used as adjuvant drugs to enhance the efficacy of antiviral drugs (such as zinc plus hydroxychloroquine) [29-31] or used as vaccine adjuvants [32,33]. It has been illustrated that many metal nanoparticles and metal complexes exhibit excellent anti-inflammatory and antiviral activities [27, 28]. Some metal-organic complexes can also inhibit the replication of SARS-CoV-2 virus through targets such as 3-chymotrypsin-like protease $\left(3 \mathrm{CL}^{\mathrm{pro}}\right)$, major protease $\left(\mathrm{M}^{\mathrm{pro}}\right)$, and papain-like protease $\left(\mathrm{PL}^{\mathrm{pro}}\right)$ [34-36]. To date, many antiviral small molecule drugs have already been proved to be in the treatment of severe COVID-19 patients. For instance, dexamethasone was found to reduce deaths from SARS-CoV-2 [37], and remdesivir was demonstrated to shorten the length of hospital stay of COVID-19 patients [38]. More interestingly, dexamethasone sodium phosphate can self-assemble into a hydrogel through hydrogen bonding and metal coordination [39, 40]; and theoretically, this kind of metallohydrogel may exhibit synergetic effects in treating COVID-19 patients.

In this review, we first briefly introduce the pathogenic mechanism of CVOID-19: SRAS-CoV-2 enters cells, replicates in large quantities, and then destroys the immune system, leading to the onset of various symptoms. Then, the key roles of metal drugs and metal elements in the viral infection and immune response process are summarized. Finally, in order to combine the advantages of metal-related antiviral therapies and immune modulating therapies to combat COVID-19, the formation of a special type of metallohydrogels composed of cross-linked antiviral small molecule drugs and metal ions, and their potential applications in the treatment of COIVD-19 patients are described and discussed. Although there is a lack of clinical evaluation regarding the performance of metallic drugs in preventing or treating COVID-19, the unique role of metals is worthy of further understanding and exploration. We expect that this review can provide an innovative view of metallic drugs, especially metallohydrogels, and consequently open up a new application area for metal-based drugs.

\section{Overview of COVID-19 and SARS-CoV-2}

\subsection{Epidemiology of COVID-19}

SARS-CoV-2, the coronavirus that causes COVID-19, has been proven to be highly contagious to all age groups, whereas most patients who showed symptoms are aged 40-69 (66.68\%) [41]. Usually, patients older than 50 years old have a higher mortality rate after being infected [41]. No matter if the infected person is symptomatic or asymptomatic, the person is contagious, making the primary source of the infection be virus-infected people $[42,43]$. It has been reported that SARS-CoV-2 has multiple routes of transmission, such as respiratory droplets caused by coughing and close contact [44, 45], fecal transmission, and aerosol transmission [46].

COVID-19 has a common incubation period of 1-14 days [45, 47]. And COVID-19 patients are often accompanied by some common symptoms, such as fever, cough, myalgia, fatigue, and dyspnea [48]. In severe cases, complications including pneumonia, acute respiratory distress syndrome (ARDS), acute organ damage (including liver, heart, kidney), liver dysfunction, and neurological symptoms can be shown [49-52]. Notably, ARDS, which can lead to respiratory failure, is the main cause of death in COVID-19 patients [53].

The COVID-19 caused at least 0.22 billion infection cases and 4.5 million deaths until the start of September, 2021 [3]. Strict regulations intended to limit social contact have been imposed by most countries. And along with the vaccination campaigns, the spreading speed of SARSCoV-2 has been strongly curbed. However, developing countries such as South American countries and African countries are still at high risk. New variants that are even more contagious and fatal are still pressuring the whole world. And the long-term post-infection symptoms are severely lowering the patients' living qualities. Therefore, there is still an urgent requirement to accelerate the research on the diagnosis, vaccine, and treatment of SRASCoV-2.

\subsection{Pathogenic characteristics of SARS-CoV-2}

SARS-CoV- 2 belongs to the $\beta$-coronavirus genus, which is an enveloped positive-stranded single-stranded RNA virus with a total genome length of approximately $30 \mathrm{~kb}$. These virus particles have a round or oval shape, with a diameter ranging from 60 to $140 \mathrm{~nm}$ [54]. The structural proteins 
encoded by the genome include four types: spike (S) glycoprotein, envelope (viral envelope $\mathrm{E}$ ) protein, matrix (M) glycoprotein, and helical nucleocapsid (N) protein (Fig. 1). It should be pointed out that $\mathrm{S}$ protein is the protein that binds to human host cell receptors. $S$ protein causes virus-cell membrane fusion, which is a key step of virus invasion [55]. In addition, $\mathrm{S}$ proteins are highly affiliated to the angiotensin-converting enzyme (ACE2) receptors, which are highly expressed in human epithelial cells [56]. Although there is no strong evidence to prove the animal reservoir of SARS-CoV-2, a large amount of scientific evidence proves the origin of zoonotic diseases [57].

\subsection{Infection process of SARS-CoV-2}

The main mechanism of SARS-CoV-2 entry into cells is recognition by angiotensin-converting enzyme 2 (ACE2) receptor and cleavage of transmembrane serine proteinase 2 (TMPRSS2) [58, 59].

Take alveolar cells as an example. There are two possible ways for the viral genome to enter the host cell: (1) endocytosis; (2) fusion (Fig. 2) [59-61]. During endocytosis, the $\mathrm{S}$ protein, which is located on the surface of SARS-CoV-2, recognizes and specifically binds to the ACE2 receptor on the cell membrane of lung epithelial cells. Then endocytosis occurs, allowing the virus to enter the host cell. The possible fusion process is that after the $\mathrm{S}$ protein recognizes the ACE2 receptor, TMPRSS2 activates the $\mathrm{S}$ protein and cleaves the binding site. Then the $\mathrm{S}$ protein fuses with the host cell membrane, and the virus core enters the cell. The lysosome of the host cell digests helical $\mathrm{N}$ protein, and the viral genome is released. After the viral genome entering, the viral RNA replicates in the host cell. The new viral protein is synthesized and then forms progeny viral particles with RNA. The newly synthesized virus particles are transported out of the cell via

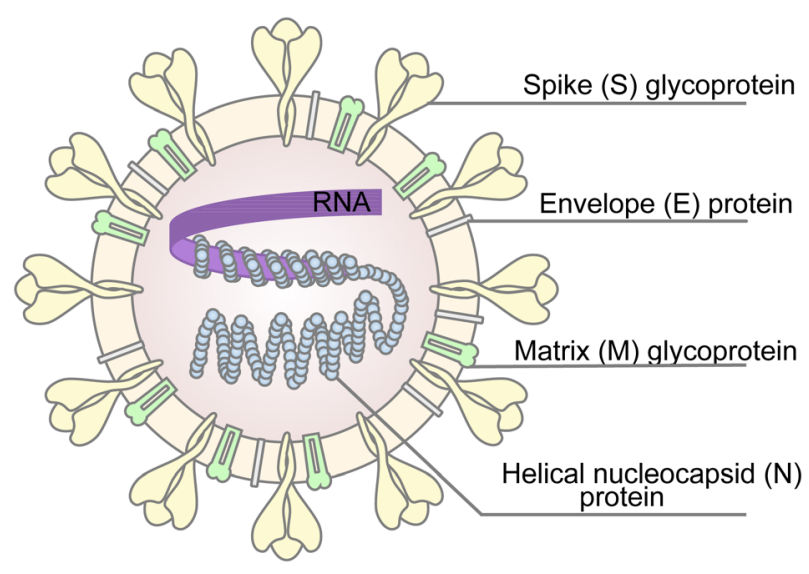

Fig. 1 Structure of SARS-CoV-2 exocytosis, and a new round of infection begins. Eventually, the virus infects alveolar cells [62]. As metal-related drugs may block the virus entry process and/or directly inhibit viral replication, destruct viral structure, or inhibit the activity of key enzymes [16, 17, 63], they can be applied to the prevention and treatment of COVID-19.

\subsection{Immune response of COVID-19 patient}

Immune imbalance and excessive inflammation activation are closely related to the disease progression and poor prognosis of COVID-19 patients [54, 64]. The host's innate and adaptive response, the balance between the virus's toxicity and the ability to evade the host's immune response, together determine the outcome of the disease [65].

\subsubsection{Body's innate immune response}

Once the SARS-CoV-2 virus invades host cells, the body initiates innate immune defense. Cells at the infected site are stimulated by the virus, which produces cytokines. Then macrophages and monocytes are activated and release a large number of cytokines, such as interferon I/III (IFN), pro-inflammatory tumor necrosis factor- $\alpha$ (TNF- $\alpha$ ), interleukin-1 (IL-1), interleukin-6 (IL-6), interleukin-8 (IL8 ), monocyte chemotactic protein 1 (MCP-1), and macrophage inflammatory protein $1 \alpha(\mathrm{MIP} 1 \alpha)$. Furthermore, the activated macrophages induce NK cells activation. NK cells then kill and destroy infected cells [65]. If the body's immune regulation function is expected, the infection will be controlled. On the contrary, the concentration of multiple cytokines will increase abnormally. High concentrations of cytokines will trigger the hyper-inflammatory response and the cytokine storm.

The NK cells decreased significantly in patients with severe COVID-19 symptoms, and the immune function was inhibited by the up-regulation of the natural killer group 2 member A (NKG2A) expression on the surface of NK cells. The ability of NK cells to secrete CD107 $\alpha$, IFN$\gamma$, IL-2, and TNF- $\alpha$ is thus down-regulated. This downregulation will lead to a decline in anti-infection ability, weakened immune regulation, and worsening of the disease [66].

\subsubsection{Body's adaptive immune response}

When the innate immune system is unable to resist SARSCoV-2, further attacks by the virus will activate the adaptive immune response. Dendritic cells (DC) become mature after receiving antigen stimulation and then activate $\mathrm{T}$ cells. $\mathrm{CD} 4+\mathrm{T}$ cells in $\mathrm{T}$ cells can promote and activate $\mathrm{CD} 8+\mathrm{T}$ cells to directly attack and kill infected cells. 


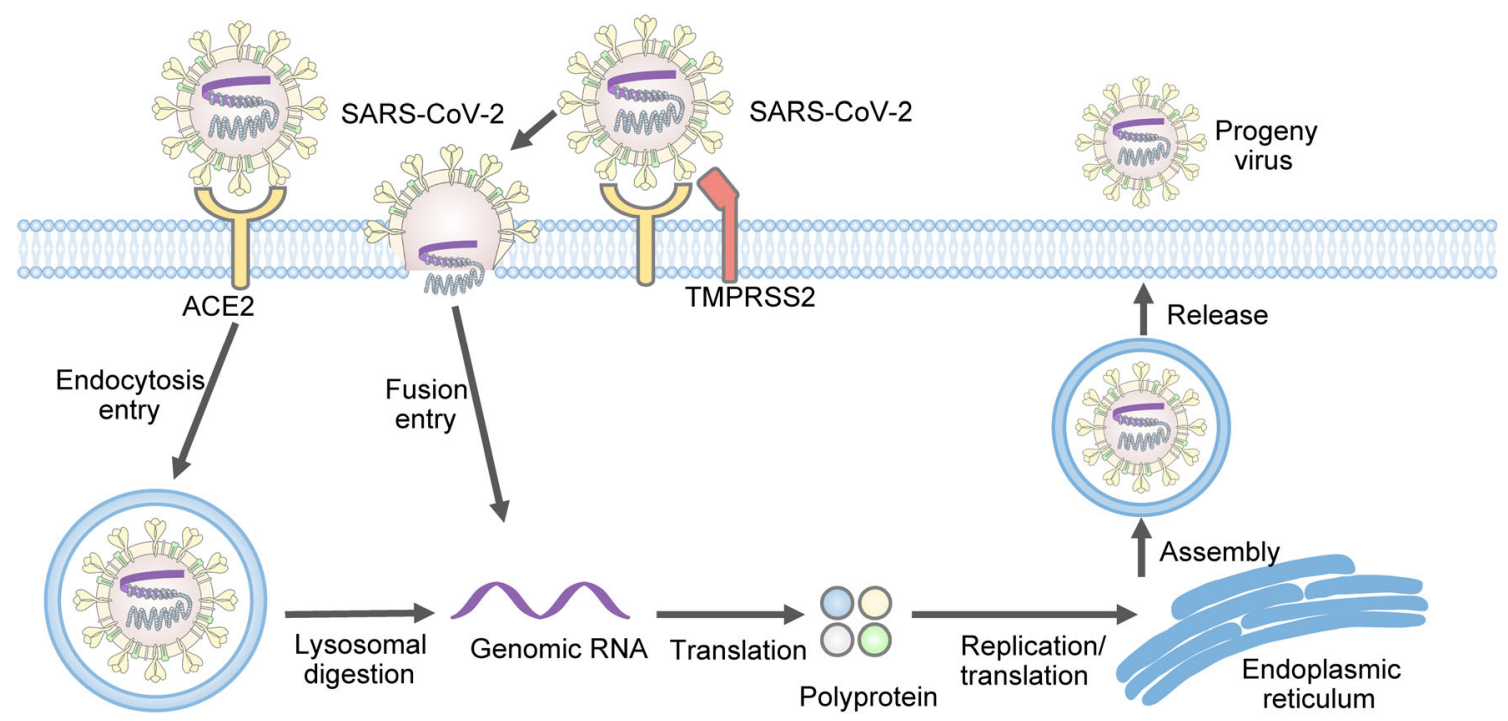

Fig. 2 Simplified SARS-CoV-2 life cycle

Moreover, this cell will also differentiate into Th1 cells to activate B cells. The B cells can differentiate into plasma cells responsible for secreting antibodies and memory cells with a specific ability to recognize antigens. Plasma cells produce a large number of virus-specific neutralizing antibodies, such as $\operatorname{IgM}, \operatorname{IgG}$, and $\operatorname{IgA}[64,65,67]$.

As is known to all, some trace metal elements benefit from regulating the body's immune response and enhancing resistance [27, 29-33, 35, 36]. Therefore, metal nutrients will play an essential and beneficial role in alleviating excessive inflammation and producing neutralizing antibodies.

\section{Metal-related prevention and treatment strategies}

Metallodrugs such as metal nutrients and metal compounds can play an important role in the prevention and treatment of COVID-19. At present, two methods are used to discover potential metal-based drugs for COVID-19: repurposing existing medications and developing new drugs $[27,28]$. These metallodrugs might directly inhibit virus replication [68, 69], prevent viruses from entering cells [63], or inhibit the activity of critical enzymes in the process of virus replication [34-36, 70, 71]. Furthermore, the combination of antiviral drugs and metals can be more effective.

There are several reasons for metal-based drugs to prevent and treat COVID-19: (1) The effect on the body attacked by the virus: participate in the immune system; inhibit the virus from entering cells; and inhibit virus replication. (2) Metal-related drugs play a synergistic effect: enhance the efficacy of antiviral drugs; vaccine adjuvants; and topical antiviral materials. (3) A metal antiviral hydrogel is proposed as a promising method to combat COVID-19 [29-31].

\subsection{Metal nutrient elements participate in immune response}

People with metal deficiency are susceptible to COVID-19 $[16,18,19,23,72]$, which may be due to being out of balance in immune regulation. Supplementing metal nutrients in the early stages of infection can help support optimal immune function and be used as a preventive strategy for high-risk groups [73]. Therefore, metal nutrients could be beneficial to reduce the infection of COVID19 and even the rate of severe illness and mortality (Fig. 3).

\subsubsection{Zinc}

Zinc ( $\mathrm{Zn}$ ) ion is a critical element of the body's immune balance, and especially it is urgently needed by hosts and pathogens. It is essential for regulating the growth and function of immune cells, and $\mathrm{Zn}$ homeostasis can regulate cell signal transduction [74, 75]. More importantly, longterm hypozincemia may be a factor related to the risk of COVID-19 [22]. Patients with poor clinical outcomes have significantly lower serum zinc levels than those with good clinical outcomes [19]. The lack of $\mathrm{Zn}$ will cause more complications in COVID-19 patients, associated with more extended hospital stay and increased patient mortality [20].

Zn has many functions: (1) enhance the ability of innate immunity and adaptive immunity in the process of virus infection [76]; (2) help improve the response of the virus to Type I interferon (IFN-1); (3) enhance the production of IFN- $\alpha$ to counteract the antagonistic effect of SARA-CoV- 


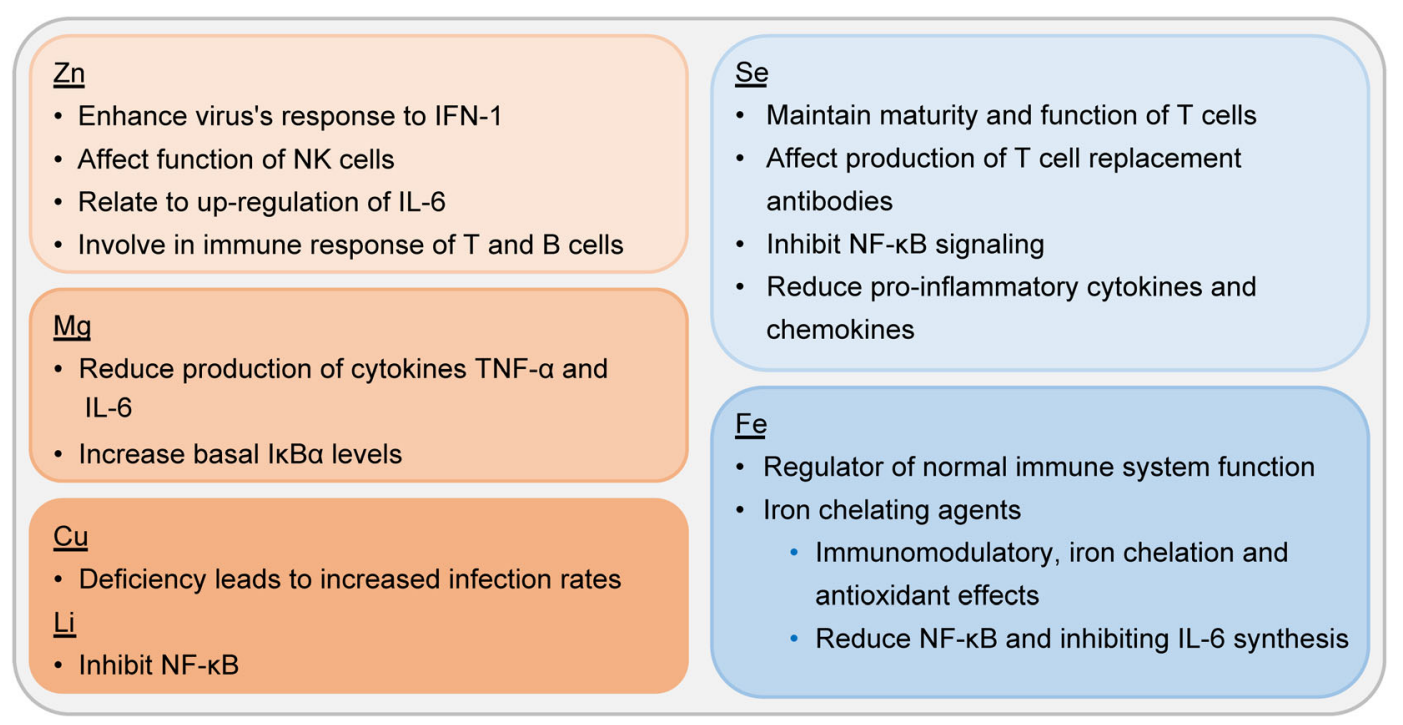

Fig. 3 Metal elements participate in immune regulation of COVID-19 patients

2 virus protein on IFN [77]; (4) promote the proliferation and differentiation of $\mathrm{T}$ and $\mathrm{B}$ lymphocytes, thereby improving immune function [78]. Low levels of $\mathrm{Zn}$ can affect the function of NK cells and are related to the upregulation of interleukin-6 (IL-6) [76]. In addition, Zn supplementation may facilitate COVID-19 treatment and patient recovery. Finzi [79] reported that four COVID-19 cases treated with high-dose oral $\mathrm{Zn}$ salts showed improvement in symptoms within $24 \mathrm{~h}$. Moreover, Finzi [80] analyzed the situation of 28 COVID-19 patients treated with $\mathrm{Zn}$ and found that patients' symptoms began to improve on average 1.6 days after $\mathrm{Zn}$ treatment, and all patients improved after seven days.

\subsubsection{Selenium}

Selenium $(\mathrm{Se})$ is one of the indispensable trace elements in the human body, and it has effective anti-inflammatory, antioxidant, and immune regulation functions [81]. The lack of Se will enhance the RNA viruses' mutation, reproduction, and virulence [15]. An observational study found that the Se level in serum samples of surviving patients with COVID-19 was significantly higher than that of non-surviving patients [23]. In some areas of China, the cure rate of COVID-19 patients is significantly positively correlated with the local Se level [82]. The serum Se level of patients in southern India was significantly lower than that of apparently healthy individuals [83].

Selenium is the active ingredient of many antioxidant enzymes. The selenium-dependent enzyme, glutathione peroxidase 1 (GPX1), is an antioxidant [84]. GPX1 can scavenge reactive oxygen species (ROS) and free radicals in host cells, thereby avoiding the increase of oxidative stress and the mutation of the viral genome [84]. Zhang et al. [85] found that increasing Se intake can promote the production of redox-active selenium, which may inhibit SARS-CoV-2 protease. Se plays an essential role in the maintenance, maturation, and function of $\mathrm{T}$ cells, as well as in the production of $\mathrm{T}$ cell replacement antibodies [86]. The inhibition of NK- $\mathrm{KB}$ signaling by $\mathrm{Se}$ can avoid excessive immune and inflammatory responses, downregulate the release of pro-inflammatory cytokines and chemokines, and prevent the occurrence of cytokine storms [87]. Therefore, it could be considered that Se supplementation is beneficial to the cure of COVID-19 patients and can also prevent SARS-CoV-2 infection.

\subsubsection{Magnesium}

Magnesium $(\mathrm{Mg})$ is the principal cation in human cells and an essential element necessary to maintain the normal physiological functions of cells. Mg has a lot of functions, such as anti-inflammatory, antioxidant, vasodilator, and neuroprotective effects [24]. The insufficiency of $\mathrm{Mg}$ can cause adverse symptoms such as a decrease in the number of $\mathrm{T}$ cells, a copious production of inflammatory cytokines in the plasma, and impaired retinal function [72]. These symptoms may lead to critical illness and complications of COVID-19. $\mathrm{Mg}$ reduces the production of inflammatory cytokines. Sugimoto et al. [88] discovered that Mg reduced the generation of cytokines TNF- $\alpha$ and IL- 6 in the maternal, term, and premature infants. They also found that magnesium could increase basal I $\mathrm{K} \mathrm{B} \alpha$ levels, and it was linked to decreased activation and nuclear localization of NF- $\kappa B$ under TLR stimulation. Therefore, Mg supplementation might have a potential impact on avoiding 
cytokine storms. An observational survey of patients with COVID-19 showed that there was a significant reduction in patients aged $\geq 50$ years who received oral vitamin D3 (1000 IU), $\mathrm{Mg}(150 \mathrm{mg})$, and vitamin B12 (500 $\mu \mathrm{g})$ supplements every day for 14 days [89]. Furthermore, supplementing phosphate, $\mathrm{Mg}$, and vitamin $\mathrm{D}$ is beneficial to the regeneration of ATP consumed by cytokine storms. This preventive strategy for high-risk groups helps prevent complications [25].

\section{1 .4 Iron}

Iron $(\mathrm{Fe})$ is a recognized regulator of normal immune system function. COVID-19 infection and pathogenesis are related to abnormal iron metabolism in the body [16]. Multiple pieces of evidence indicate that low serum $\mathrm{Fe}$ levels are related to the severity and fatality rate of COVID-19 [90, 91]. The increase in ferritin concentration is correlated with the severity of the disease. Because of the excessive release of cytokines, COVID-19 is considered part of the symptoms of ferritin syndrome, and Fe depletion therapy has been proposed [92]. In the control and treatment of COVID-19 infection and its complications, Fe chelating agents have potential immunomodulatory, $\mathrm{Fe}$ chelation, and antioxidant effects [93]. Fe chelating agents can be used as an auxiliary drug to reduce ARDS and help to control the infection of the SARS-CoV-2 virus to human organs by reducing NF- $\mathrm{KB}$ and inhibiting IL- 6 synthesis [93]. Deferoxamine can reduce the level of IL-6 and inflammatory response in the endothelium in vitro through its chelation and immunomodulatory effects, thereby reducing the severity of SARS-CoV-2 infection and improving the therapeutic effect [94]. From binding to the receptors of the coronavirus, the Fe chelator lactoferrin (Lf) can prevent the virus from entering the host cells [17]. Therefore, it is a potential application to Fe chelator for the treatment of COVID-19.

\subsubsection{Other metal nutrient elements}

Copper $(\mathrm{Cu})$ is involved in the functions of critical immune cells, and the lack of copper is associated with the increase in infection rates [95]. Lithium (Li) seems to inhibit NF- $\mathrm{BB}$ and may play a role in inflammation caused by SARSCoV-2 infection [96].

The supplementation of trace metal nutrients helps the recovery of physiological immunity and reduces inflammation and oxidative stress. It is necessary to build a robust immune system and resist the epidemic of COVID-19. Therefore, metal nutrients are of great importance.

\subsection{Metallodrugs inhibiting virus from entering cells}

Metal nanomaterials are common metal-based drugs that can prevent SARS-CoV-2 from entering cells. Silver and silver nanomaterials (AgNPs) have been widely explored in pharmaceutical preparations due to their remarkable antiviral and antibacterial effects [97]. Jeremiah et al. [98] observed that AgNPs with diameters ranging 2-15 nm have efficacious inhibition of the SARS-CoV-2 virus around the cell at concentrations between $1 \times 10^{-6}$ and $10 \times 10^{-6}$. And they also found that AgNPs effectively inhibit the entry of viruses into cells by destroying the integrity of the viruses. It must be noted that AgNPs show cytotoxic effects at concentrations of $20 \times 10^{-6}$ and above. A molecular dynamics (MD) simulation showed that gold nanoparticles functionalized by novel peptides (AuNP-Pep) had a more stable binding ability to receptor binding domains (RBD) than ACE2. This novel peptide was designed based on the 15 amino acids of ACE2 (Fig. 4a-c) [63]. Therefore, this composite nanostructure could potentially block the RBD of SARS-CoV-2. Experiments also suggested that these AuNP-pep could prevent SARSCoV-2 from entering host cells by interfering host cells from recognizing the viral $\mathrm{S}$ protein. Iron oxide nanoparticles (IONPs) are a drug approved by the FDA for the treatment of anemia, and it has been proven to have in vitro antiviral activity and have the ability to limit virus replication and further infection. Abo-Zeid et al. [99] revealed that IONPs $\left(\mathrm{Fe}_{2} \mathrm{O}_{3}\right.$ and $\left.\mathrm{Fe}_{3} \mathrm{O}_{4}\right)$ are related to SARS-CoV-2 virus protein conformation changes and virus inactivation through molecular docking studies (Fig. 4 d, e). $\mathrm{Fe}_{3} \mathrm{O}_{4}$ could bind to S1-RBD to form a stable structure. And the combination of IONPs with S1-RBD could generate ROS, resulting in the destruction of the virus structure. Therefore, IONPs can restrict virus entry into cells and further infection.

Metal complexes have a wide range of structural changes and diverse stereochemistries due to their multiple specific ligand combinations. They are drugs with strong adaptability. Chuong et al. [100] proved that the two pentamethylcyclopentadienyl $\left(\mathrm{Cp}^{*}\right)$ rhodium piano stool complexes (Fig. 5) showed direct virucidal activity against SARS-CoV-2 and speculated that the complexes might act on the $\mathrm{S}$ protein on the surface of the virus.

Sodium selenite can oxidize the thiol group in the viral protein disulfide isomerase [101]. Therefore, Kieliszek and Lipinski [102] hypothesized that selenite could inhibit viruses entering healthy cells and eliminate their infectivity. 

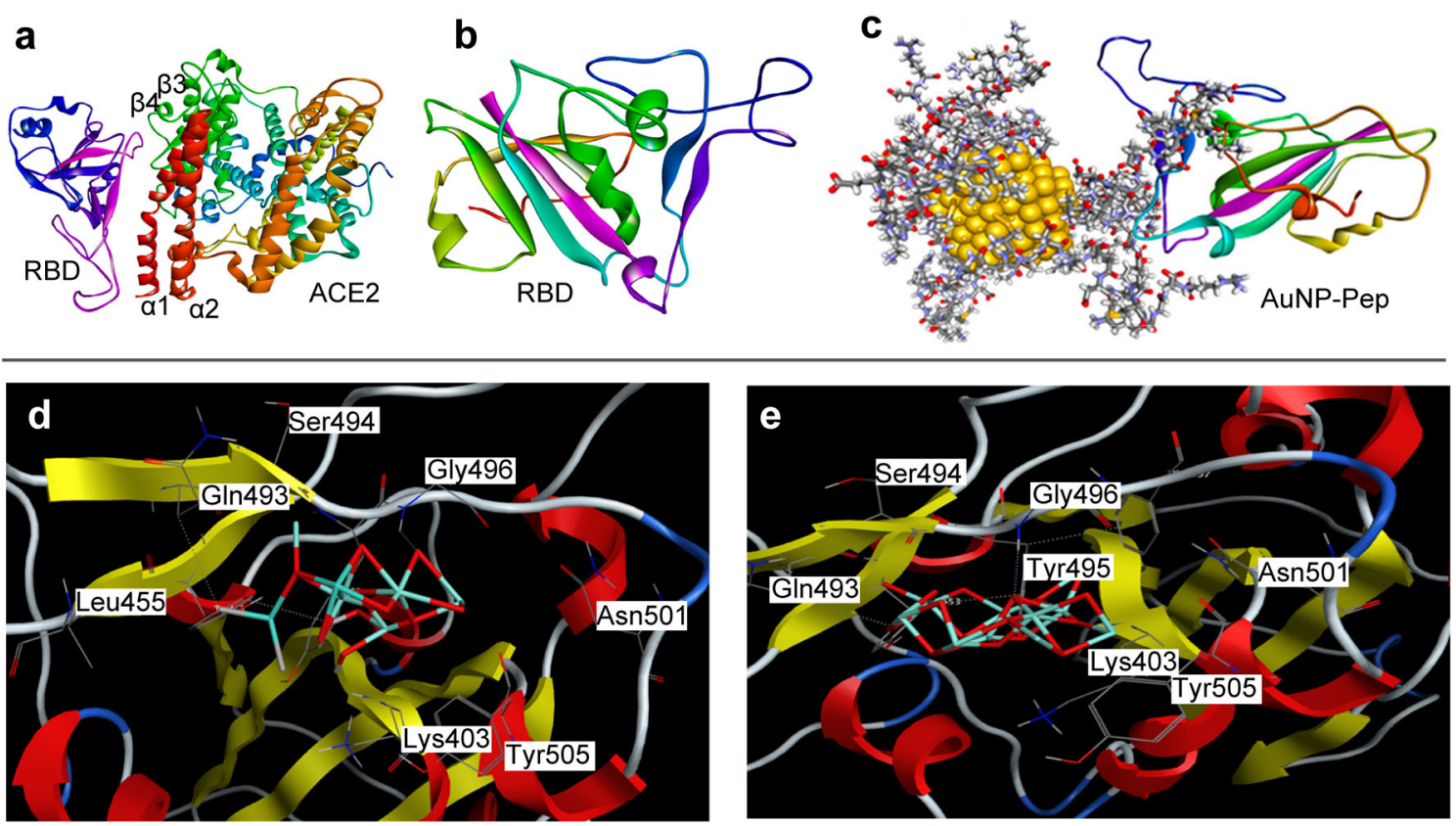

Fig. 4 Obtained structures of RBD of SARS-CoV-2 in a presence and $\mathbf{b}$ absence of ACE2, after 100 MD simulations in physiological solution; c structures of RBD complexes with AuNP-Pep after simulation. Reproduced with permission from Ref. [63]. Copyright 2020, American Chemical Society. 3D interaction diagram showing d $\mathrm{Fe}_{2} \mathrm{O}_{3}$ and e $\mathrm{Fe}_{3} \mathrm{O}_{4}$ docking interactions with key amino acids in S-RBD of SARS-CoV-2. Reproduced with permission from Ref. [98]. Copyright 2020, Elsevier

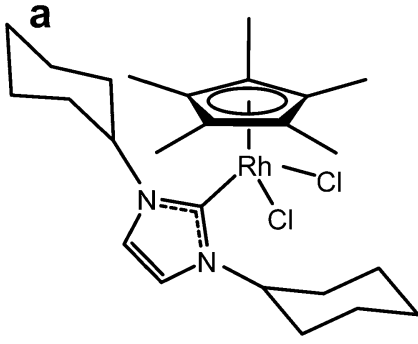

$\mathrm{Cp}$ Rh(ICy) $\mathrm{Cl}_{2}$

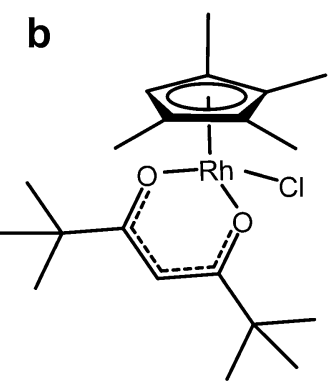

$C p * \operatorname{Rh}(d p v m) C l$
Fig. 5 Two pentamethylcyclopentadienyl $\left(\mathrm{Cp}^{*}\right)$ rhodium piano stool complexes: a $\mathrm{Cp}{ }^{*} \mathrm{Rh}(1,3-$ dicyclohexylimidazol-2-ylidene) $\mathrm{Cl}_{2}$; b $\mathrm{Cp}^{*} \mathrm{Rh}$ (dipivaloylmethanato)Cl

\subsection{Metallodrugs inhibiting virus replication}

Some metal nanoparticles have shown antiviral properties, which can be effective in treating COVID-19 patients $[27,28]$. Auranofin is an FDA-approved nano-gold drug that exhibits antiviral properties. Rothan et al. [68] reported that low micromolar concentrations of auranofin could inhibit replication of SARS-CoV-2 in human cells and result in a reduction in SARS-CoV-2-induced cytokines by its antiviral and anti-inflammatory properties. The removal of SARSCoV-2 RNA in cells treated with auranofin was quite significant, showing a $95 \%$ reduction at $48 \mathrm{~h}$ after infection. Some metal compounds may inhibit the virus replication process and reduce the symptoms of virus infection. Some bismuth salts have shown efficacy against the SARS-CoV-2 virus in vitro [70, 71]. As a dose-dependent agent, bismuth potassium citrate (BPC) can significantly inhibit the nucleoside triphosphate hydrolase (NTPase) and RNA helicase activities of SARS-CoV-2 non-structural protein 13 (nsp13) [70]. Ranitidine bismuth citrate (RBC) not only effectively inhibits NTPase and RNA helicase activities, but also shows an inhibitory effect on the ATPase (half maximal inhibitory concentration of $\mathrm{IC}_{50}=0.69 \mu \mathrm{mol} \cdot \mathrm{L}^{-1}$ ) and DNA-unwinding $\left(\mathrm{IC}_{50}=0.70 \mu \mathrm{mol} \cdot \mathrm{L}^{-1}\right)$ activity of SARS-CoV-2 helicase [71]. $\operatorname{Re}(\mathrm{I})$ tricarbonyl complexes can reduce the activity of the 3-chymotrypsin-like protease $\left(3 \mathrm{CL}^{\text {pro }}\right.$, $\left.\mathrm{IC}_{50}=7.5-24.1 \mu \mathrm{mol} \cdot \mathrm{L}^{-1}\right)$, which is the SARS-CoV-2 main cysteine protease [34]. Karges et al. [34] synthesized and characterized a range of $\operatorname{Re}(\mathrm{I})$ tricarbonyl complexes capped by chloride and water ligands and investigated their activity in vitro. The aqua compounds show significant inhibition activity of the $3 \mathrm{CL}^{\text {pro }}$, possibly via reacting with the Cys145 active site residue (Fig. 6). Scior et al. [35] conducted computer simulations and reported that some vanadium complexes could combine with the major protease $\left(\mathrm{M}^{\mathrm{pro}}\right)$ of SARS-CoV-2 to inhibit virus replication. Gold metallodrugs are efficient inhibitors of SARS-CoV-2's papain-like protease $\left(\mathrm{PL}^{\mathrm{pro}}\right)$, which plays a key role in virus replication [36]. Haribabu et al. [103] synthesized three $\mathrm{Pd}(\mathrm{II})$ complexes. These complexes have a higher affinity for the $\mathrm{M}^{\text {pro }}$ of SARS-CoV-2 than that with chloroquine and hydroxychloroquine. Pectol et al. [104] proved that 

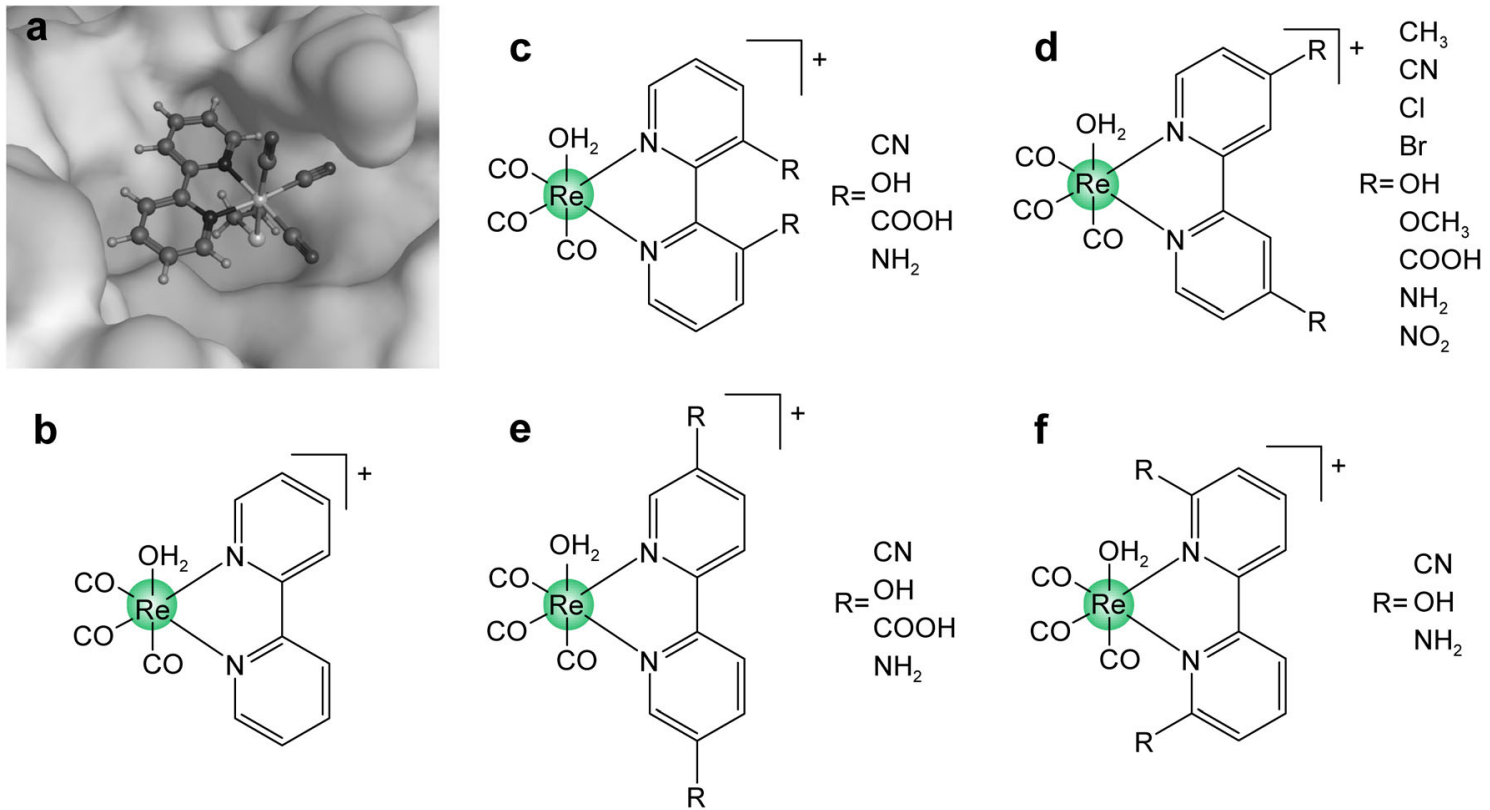

Fig. 6 a Docking pose of $\left[\operatorname{Re}\left(2,2^{\prime} \text {-bipyridine }\right)(\mathrm{CO})_{3}\right]^{+}$fragment bound to thiol of Cys 145 in active site of $3 \mathrm{CL}^{\text {pro; }}$; chemical structure of $\operatorname{Re}(\mathrm{I})$ tricarbonyl complexes: b $\operatorname{Re} 1$; c $\operatorname{Re} 2-5$; d Re6-14; e Re15-18; f Re19-21. Reproduced with permission from Ref. [34]. Copyright 2021, Wiley Online Library

dinitroso-iron complexes (DNICs) could be used as inhibitors of SARS-CoV-2 $\mathrm{M}^{\text {pro }}$ through computer prediction and external studies. In addition, Bernstein and Zhang [69] used gallium maltolate $(\mathrm{GaM})$ to treat SARS-CoV-2-infected Vero E6 cells to evaluate the antiviral ability. Its ability to prevent virus replication has been proven, and its efficacy is related to dosage. The concentration for $50 \%$ of maximal effect $\left(\mathrm{EC}_{50}\right)$ of $\mathrm{GaM}$ was about $14 \mu \mathrm{mol} \cdot \mathrm{L}^{-1}$, and cytotoxicity was not observed at a concentration of at least $200 \mu \mathrm{mol} \cdot \mathrm{L}^{-1}$.

\subsection{Improving efficacy of antiviral drugs}

The use of antiviral drugs in combination with metal drugs can enhance efficacy and reduce side effects. Morad et al. [105] wrapped hydroxychloroquine on $\mathrm{Ag}, \mathrm{Au}$, and $\mathrm{Pt}$ nanoparticles and then conducted first-principles simulations of these particles. The results show that as a drug delivery system, precious metal nanoparticles (NPs) with antiviral and antibacterial properties can reduce side effects. Chloroquine/hydroxychloroquine combined with zinc or zinc complexes may enhance their clinical efficacy [30, 31]. Quinoline-based $\mathrm{Cu}(\mathrm{II})$ complexes are designed and synthesized as potential drugs against COVID-19 [106].

\subsection{Metallodrugs as vaccine adjuvants to prevent COVID-19}

Metal nanoparticles and metal salts can be used as SARSCoV-2 vaccine adjuvants [107-109]. PiCoVacc, a purified vaccine candidate using an alum adjuvant, can protect rhesus monkeys challenged by SARS-CoV-2 [32]. Gold nanoparticles (AuNPs) functionalized with SH-PEG-NH have the potential to become a vaccine adjuvant [33].

\subsection{Metal antiviral materials blocking spread of SARS-CoV-2}

Adding antivirus coatings to masks, protective clothing, or touch surfaces (such as door handles and railings) can effectively inhibit the spread of the virus. Hosseini et al. [110] described a copper oxide porous hydrophilic coating, which can effectively reduce the SARS-CoV-2 virus infection rate and has good stability. Nonwoven masks with shellac/copper nanoparticles (CuNPs) nanocoating hybrid will be self-sterilizing and reusable [111]. Copper@ZIF-8 core-shell nanowires can impart antimicrobial activity to a medical-grade mask by processing the mask's filter media [112]. Aasi et al. [113] evaluated the adsorption of hydrogen peroxide on metal-decorated single-walled carbon nanotubes. The results show that Pt-, Rh-, Ruand $\mathrm{Cu}$-single-wall carbon nanotubes are the best candidates for designing antiviral surfaces.

Silver and copper, which are regarded as common antibacterial materials, may also be effective in antivirus. Bright et al. [114] proved that copper and silver have the effect of inactivating coronaviruses. Zeolite (sodium aluminosilicate) powders amended with silver and silver/copper could cause significant reductions of human 
coronavirus 229E. Therefore, we believe that silver and copper have the potential as antiviral agents.

\subsection{Metallohydrogels as a promising antiviral drug for combating COVID-19}

Hydrogels are widely used in the medical field. Incorporating metal components into the gel matrix can result in a multifunctional gel material [115]. One of the advantages is that hydrogels can be used as carriers to slow antiviral components' release. It has been reported that the metal nanoparticles (mNPs) containing hydrogel can be used in antibacterial and anticancer treatments [116, 117]. In addition, the use of hydrogel to load paracetamol is recommended for the antipyretic treatment of COVID-19 to achieve the purpose of controlled release [118]. Therefore, metal drugs with antiviral effects are encapsulated in hydrogels to develop metal antiviral hydrogels with sustained-release effects. For example, the metal nano-drug hybrid hydrogel can be used in antiviral therapy through slow-release metal nano-drugs.

Metal ions have been proved to be effective physical cross-linkers for small molecule drugs to form hydrogels [39]. For instance, calcium ions have been employed to cross-link dexamethasone sodium phosphate to form a supramolecular hydrogel, and the anti-inflammatory effect of dexamethasone has been preserved in the resulting gel [40]. Dexamethasone has now been proved to reduce the death toll caused by SARS-CoV-2 [37]. By cross-linking dexamethasone with metal ions (e.g., $\mathrm{Ca}^{2+}, \mathrm{Zn}^{2+}$ ) to form a hydrogel, a safe and effective formulation of dexamethasone can be introduced to the patients. And by varying the ratio of dexamethasone/ion, the release rate of dexamethasone can be controlled. Moreover, through local injection or aerosolization of the hydrogel and inhalation, hydrogel prepared by non-covalent bonding between small antivirus molecules and metal ions can be applied directly to the lesion, providing a more efficient cure to COVID-19 patients.

\section{Summary and outlook}

In summary, this review briefly introduces the pathogenesis of COVID-19 and outlines current strategies in the prevention and treatment of COVID-19 using metal-related drugs. These preventions and treatment programs are mainly based on two approaches: immune regulation and antiviral therapy. Trace metal nutrients can regulate the body's immune system and intervene in the process of viral infection, while many metallodrugs have been used as antiviral drugs, enzyme inhibitors, auxiliary drugs, and vaccine adjuvants. Therefore, it is worth attempting to develop new metallodrugs and repurposing existing metallodrugs. Based on the various applications of metallohydrogels in the medical field, the development of metallohydrogels may open up a new era of metallodrug. Nevertheless, there is still a lack of data and clinical trials to verify the efficacy and safety of metal-based drugs in curing COVID-19. Further researches and evaluations remain necessary.

Acknowledgements This work was financially supported by Hunan Provincial Key Laboratory of Micro \& Nano Materials Interface Science, the National Natural Science Foundation of China (Nos. 21773311 and 21972169), Hunan Provincial Science and Technology Plan Project, China (No. 2019TP1001).

\section{Declarations}

Conflicts of interests The authors declare that they have no conflict of interest.

\section{References}

[1] Zhu N, Zhang DY, Wang WL, Li XW, Yang B, Song JD, Zhao X, Huang BY, Shi WF, Lu RJ, Niu PH, Zhan FX, Ma XJ, Wang DY, Xu WB, Wu GZ, Gao GF, Tan WJ. A novel coronavirus from patients with pneumonia in China, 2019. N Engl J Med. 2020;382(8):727.

[2] Wu YT, Ho WZ, Huang YW, Jin DY, Li SY, Liu SL, Liu XF, Qiu JM, Sang YM, Wang QH, Yuen KY, Zheng ZM. SARS-CoV-2 is an appropriate name for the new coronavirus. The Lancet. 2020;395(10228):949.

[3] Dong ES, Du HR, Gardner L. An interactive web-based dashboard to track COVID-19 in real time. Lancet Infect Dis. 2020;20(5):533.

[4] Zhu YF, Li J, Pang ZQ. Recent insights for the emerging COVID-19: drug discovery, therapeutic options and vaccine development. Asian J Pharm Sci. 2021;16(1):4.

[5] Asselah T, Durantel D, Pasmant E, Lau G, Schinazi RF. COVID-19: discovery, diagnostics and drug development. J Hepatol. 2021;74(1):168.

[6] Saghazadeh A, Rezaei N. Towards treatment planning of COVID-19: rationale and hypothesis for the use of multiple immunosuppressive agents-anti-antibodies, immunoglobulins, and corticosteroids. Int Immunopharmacol. 2020;84: 106560.

[7] Izda V, Jeffries MA, Sawalha AH. COVID-19: a review of therapeutic strategies and vaccine candidates. Clin Immunol. 2021;222:108634.

[8] Karpinski TM, Ozarowski M, Seremak-Mrozikiewicz A, Wolski H, Wlodkowic D. The 2020 race towards SARS-CoV-2 specific vaccines. Theranostics. 2021;11(4):1690.

[9] Ledford H. Six months of COVID vaccines: what 1.7 billion doses have taught scientists. Nature. 2021;594(7862):164.

[10] Sim F. Early Covid-19 vaccination rollout: a commentary from England. Isr J Health Policy Res. 2021;10(1):18.

[11] Rosen B, Waitzberg R, Israeli A. Israel's rapid rollout of vaccinations for COVID-19. Isr J Health Policy Res. 2021; 10(1):6.

[12] Becker RC. Anticipating the long-term cardiovascular effects of COVID-19. J Thromb Thrombolysis. 2020;50(3):512.

[13] Nalbandian A, Sehgal K, Gupta A, Madhavan MV, McGroder C, Stevens JS, Cook JR, Nordvig AS, Shalev D, Sehrawat TS, 
Ahluwalia N, Bikdeli B, Dietz D, Der-Nigoghossian C, Liyanage-Don N, Rosner GF, Bernstein EJ, Mohan S, Beckley AA, Seres DS, Choueiri TK, Uriel N, Ausiello JC, Accili D, Freedberg DE, Baldwin M, Schwartz A, Brodie D, Garcia CK, Elkind MSV, Connors JM, Bilezikian JP, Landry DW, Wan EY. Post-acute COVID-19 syndrome. Nat Med. 2021;27(4): 601.

[14] Sandra LL, Talia WO, Carol P, Rosalinda S, Paulina R, Angelica C, Sonia V. More than 50 long-term effects of COVID-19: a systematic review and meta-analysis. Res Sq. 2021. https://doi.org/10.21203/rs.3.rs-266574/v1.

[15] Hiffler L, Rakotoambinina B. Selenium and RNA virus interactions: potential implications for SARS-CoV-2 infection (COVID-19). Front Nutr. 2020;7:164.

[16] Lawaczeck R. COVID-19 and body iron: a survey on phenomenological and genetic correlations. ACS Chem Neurosci. 2020;11(24):3996.

[17] Habib HM, Ibrahim S, Zaim-AIbrahim WH. The role of iron in the pathogenesis of COVID-19 and possible treatment with lactoferrin and other iron chelators. Biomed Pharmacother. 2021;136:111228.

[18] Hackler J, Heller RA, Sun Q, Schwarzer M, Diegmann J, Bachmann M, Moghaddam A, Schomburg L. Relation of serum copper status to survival in COVID-19. Nutrients. 2021; 13(6): 1898.

[19] Dubourg G, Lagier JC, Brouqui P, Casalta JP, Jacomo V, La Scola B, Rolain JM, Raoult D. Low blood zinc concentrations in patients with poor clinical outcome during SARS-CoV-2 infection: is there a need to supplement with zinc COVID-19 patients? J Microbiol Immunol Infect. 2021. https://doi.org/10. 1016/j.jmii.2021.01.012.

[20] Jothimani D, Kailasam E, Danielraj S, Nallathambi B, Ramachandran H, Sekar P, Manoharan S, Ramani V, Narasimhan G, Kaliamoorthy I, Rela M. COVID-19: poor outcomes in patients with zinc deficiency. Int J Infect Dis. 2020; 100:343.

[21] Wessels I, Rolles B, Rink L. The potential impact of zinc supplementation on COVID-19 pathogenesis. Front Immunol. 2020;11:1712.

[22] Yasui Y, Yasui H, Suzuki K, Saitou T, Yamamoto Y, Ishizaka T, Nishida K, Yoshihara S, Gohma I, Ogawa Y. Analysis of the predictive factors for a critical illness of COVID-19 during treatment relationship between serum zinc level and critical illness of COVID-19. Int J Infect Dis. 2020;100:230.

[23] Moghaddam A, Heller RA, Sun Q, Seelig J, Cherkezov A, Seibert L, Hackler J, Seemann P, Diegmann J, Pilz M, Bachmann M, Minich W, Schomburg L. Selenium deficiency is associated with mortality risk from COVID-19. Nutrients. 2020;12(7):2098.

[24] Tang CF, Ding H, Jiao RQ, Wu XX, Kong LD. Possibility of magnesium supplementation for supportive treatment in patients with COVID-19. Eur J Pharmacol. 2020;886:173546.

[25] van Kempen T, Deixler E. SARS-CoV-2: influence of phosphate and magnesium, moderated by vitamin $\mathrm{D}$, on energy (ATP) metabolism and on severity of COVID-19. Am J Physiol Endocrinol Metab. 2021;320(1):E2.

[26] Mjos KD, Orvig C. Metallodrugs in medicinal inorganic chemistry. Chem Rev. 2014;114(8):4540.

[27] Cirri D, Pratesi A, Marzo T, Messori L. Metallo therapeutics for COVID-19. Exploiting metal-based compounds for the discovery of new antiviral drugs. Expert Opin Drug Discov. 2021;16(1):39.

[28] de Paiva REF, Marcal Neto A, Santos IA, Jardim ACG, Corbi PP, Bergamini FRG. What is holding back the development of antiviral metallodrugs? A literature overview and implications for SARS-CoV-2 therapeutics and future viral outbreaks. Dalton Trans. 2020;49(45):16004.

[29] Kelleni MT. Resveratrol-zinc nanoparticles or pterostilbene-zinc: potential COVID-19 mono and adjuvant therapy. Biomed Pharmacother. 2021;139:111626.

[30] Derwand R, Scholz M, Zelenko V. COVID-19 outpatients: early risk-stratified treatment with zinc plus low-dose hydroxychloroquine and azithromycin: a retrospective case series study. Int J Antimicrob Agents. 2020;56(6):106214.

[31] Derwand R, Scholz M. Does zinc supplementation enhance the clinical efficacy of chloroquine/hydroxychloroquine to win today's battle against COVID-19? Med Hypotheses. 2020;142: 109815.

[32] Gao Q, Bao LL, Mao HY, Wang L, Xu KW, Yang MN, Li YJ, Zhu L, Wang N, Lv Z, Gao H, Ge XQ, Kan B, Hu YL, Liu JN, Cai F, Jiang DY, Yin YH, Qin CF, Li J, Gong XJ, Lou XY, Shi W, Wu DD, Zhang HM, Zhu L, Deng W, Li YR, Lu JX, Li CG, Wang XX, Yin WD, Zhang YJ, Qin C. Development of an inactivated vaccine candidate for SARS-CoV-2. Science. 2020; 369(6499):77.

[33] Farfan-Castro S, Garcia-Soto MJ, Comas-Garcia M, Arevalo-Villalobos JI, Palestino G, Gonzalez-Ortega O, Rosales-Mendoza S. Synthesis and immunogenicity assessment of a gold nanoparticle conjugate for the delivery of a peptide from SARS-CoV-2. Nanomedicine. 2021;34:102372.

[34] Karges J, Kalaj M, Gembicky M, Cohen SM. Re(I) tricarbonyl complexes as coordinate covalent inhibitors for the SARS-CoV-2 main cysteine protease. Angew Chem Int Ed. 2021; 60(19): 10716

[35] Scior T, Abdallah HH, Mustafa SFM, Guevara-Garcia JA, Rehder D. Are vanadium complexes druggable against the main protease $\mathrm{M}$ (pro) of SARS-CoV-2? A computational approach. Inorganica Chim Acta. 2021;519:120287.

[36] Gil-Moles M, Basu U, Bussing R, Hoffmeister H, Turck S, Varchmin A, Ott I. Gold metallodrugs to target coronavirus proteins: inhibitory effects on the Spike-ACE2 interaction and on PLpro protease activity by auranofin and gold organometallics*. Chemistry. 2020;26(66):15140.

[37] Horby P, Lim WS, Emberson J, Mafham M, Bell J, Linsell L, Staplin N, Brightling C, Ustianowski A, Elmahi E, Prudon B, Green C, Felton T, Chadwick D, Rege K, Fegan C, Chappell LC, Faust SN, Jaki T, Jeffery K, Montgomery A, Rowan K, Juszczak E, Baillie JK, Haynes R, Landray M. Dexamethasone in hospitalized patients with Covid-19. N Engl J Med. 2021; 384(8):693.

[38] Beigel J, Tomashek K, Dodd L, Mehta A, Zingman B, Kalil A, Hohmann E, Chu HY, Luetkemeyer A, Kline S, Lopez de Castilla D, Finberg R, Dierberg K, Tapson V, Hsieh L, Patterson T, Paredes R, Sweeney D, Short W, Touloumi G, Lye D, Ohmagari N, Oh MD, Ruiz Palacios G, Benfield T, Fatkenheuer G, Kortepeter M, Atmar R, Creech C, Lundgren J, Babiker A, Pett S, Neaton J, Burgess T, Bonnett T, Green M, Makowski M, Osinusi A, Nayak S, Lane H, Members AS. Remdesivir for the treatment of Covid-19: final report. N Engl J Med. 2020;383(19):1813.

[39] Liu Q, Zhan CY, Barhoumi A, Wang WP, Santamaria C, McAlvin JB, Kohane D. A supramolecular shear-thinning anti-inflammatory steroid hydrogel. Adv Mater. 2016;28(31): 6680 .

[40] Wu W, Zhang ZL, Xiong TT, Zhao WG, Jiang R, Chen H, Li $\mathrm{XY}$. Calcium ion coordinated dexamethasone supramolecular hydrogel as therapeutic alternative for control of non-infectious uveitis. Acta Biomater. 2017;61:157.

[41] Zhang Y, Luo W, Li Q, Wang XJ, Chen J, Song QF, Tu H, Ren RQ, Li C, Li D, Zhao J, McGoogan JM, Shan D, Li B, Zhang JX, Dong YH, Jin Y, Mao S, Qian MB, Lv C, Zhu HH, Wang 
LM, Xiao L, Xu J, Yin DP, Zhou L, Li ZJ, Shi GJ, Dong XP, Guan XH, Gao GF, Wu ZY, Feng ZJ. Risk factors for death among the first 80543 COVID-19 cases in China: relationships between age, underlying disease, case severity, and region. Clin Infect Dis. 2021. https://doi.org/10.1093/cid/ciab493.

[42] Shereen M, Khan S, Kazmi A, Bashir N, Siddique R. COVID-19 infection: origin, transmission, and characteristics of human coronaviruses. J Adv Res. 2020;24:91.

[43] Arons M, Hatfield K, Reddy S, Kimball A, James A, Jacobs J, Taylor J, Spicer K, Bardossy A, Oakley L, Tanwar S, Dyal J, Harney J, Chisty Z, Bell J, Methner M, Paul P, Carlson C, McLaughlin H, Thornburg N, Tong S, Tamin A, Tao Y, Uehara A, Harcourt J, Clark S, Brostrom-Smith C, Page L, Kay M, Lewis J, Montgomery P, Stone N, Clark T, Honein M, Duchin J, Jernigan J. Public Health-Seattle and King County and CDC COVID-19 investigation team. Presymptomatic SARS-CoV-2 infections and transmission in a skilled nursing facility. N Engl J Med. 2020;382(22):2081.

[44] Chan JFW, Yuan SF, Kok KH, To KKW, Chu H, Yang J, Xing FF, Liu JL, Yip C, Poon R, Tsoi HW, Lo SKF, Chan KH, Poon VKM, Chan WM, Ip J, Cai JP, Cheng VCC, Chen HL, Hui CKM, Yuen KK. A familial cluster of pneumonia associated with the 2019 novel coronavirus indicating person-to-person transmission: a study of a family cluster. Lancet. 2020; 395(10223):514.

[45] Wang DW, Hu B, Hu C, Zhu FF, Liu X, Zhang J, Wang BB, Xiang H, Cheng ZS, Xiong Y, Zhao Y, Li YR, Wang XH, Peng ZY. Clinical characteristics of 138 hospitalized patients with 2019 novel coronavirus-infected pneumonia in Wuhan, China. JAMA. 2020;323(11):1061

[46] Mukhra R, Krishan K, Kanchan T. Possible modes of transmission of Novel coronavirus SARS-CoV-2: a review. Acta Biomed. 2020;91(3):e2020036.

[47] Lauer S, Grantz K, Bi Q, Jones F, Zheng QL, Meredith H, Azman A, Reich N, Lessler J. The incubation period of coronavirus disease 2019 (COVID-19) from publicly reported confirmed cases: estimation and application. Ann Intern Med. 2020;172(9):577.

[48] Huang CL, Wang YM, Li XW, Ren LL, Zhao JP, Hu Y, Zhang L, Fan GH, Xu JY, Gu XY, Cheng ZS, Yu T, Xia JA, Wei Y, Wu WJ, Xie XL, Yin W, Li H, Liu M, Xiao Y, Gao H, Guo L, Xie JG, Wang GF, Jiang RM, Gao ZC, Jin Q, Wang JW, Cao B. Clinical features of patients infected with 2019 novel coronavirus in Wuhan, China. Lancet. 2020;395(10223):497.

[49] Hendren N, Drazner M, Bozkurt B, Cooper L Jr. Description and proposed management of the acute COVID-19 cardiovascular syndrome. Circulation. 2020;141(23): 1903.

[50] Richardson S, Hirsch J, Narasimhan M, Crawford J, McGinn T, Davidson K, the Northwell COVID-19 Research Consortium, Barnaby D, Becker L, Chelico J, Cohen S, Cookingham J, Coppa K, Diefenbach M, Dominello A, Duer-Hefele J, Falzon L, Gitlin J, Hajizadeh N, Harvin T, Hirschwerk D, Kim EJ, Kozel M, Marrast L, Mogavero J, Osorio G, Qiu M, Zanos T. Presenting characteristics, comorbidities, and outcomes among 5700 patients hospitalized with COVID-19 in the New York City area. JAMA. 2020;323(20):2098.

[51] Mao R, Qiu Y, He JS, Li XH, Liang J, Shen J, Zhu LR, Chen Y, Lacucci M, Ng S, Ghosh S, Chen MH. Manifestations and prognosis of gastrointestinal and liver involvement in patients with COVID-19: a systematic review and meta-analysis. Lancet Gastroenterol Hepatol. 2020;5(7):667.

[52] Chen YT, Shao SC, Hsu CK, Wu IW, Hung MJ, Chen YC. Incidence of acute kidney injury in COVID-19 infection: a systematic review and meta-analysis. Crit Care. 2020;24(1): 346.
[53] Zhang BC, Zhou XY, Qiu YR, Song YR, Feng F, Feng J, Song QB, Jia QZ, Wang J. Clinical characteristics of 82 cases of death from COVID-19. PLoS ONE. 2020;15(7):e0235458.

[54] Lu RJ, Zhao X, Li J, Niu PH, Yang B, Wu HL, Wang WL, Song H, Huang BY, Zhu N, Bi YH, Ma XJ, Zhan FX, Wang L, Hu T, Zhou H, Hu ZH, Zhou WM, Zhao L, Chen J, Meng Y, Wang J, Lin Y, Yuan JY, Xie ZH, Ma JM, Liu WJ, Wang DY, Xu WB, Holmes EC, Gao GF, Wu GZ, Chen WJ, Shi WF, Tan WJ. Genomic characterisation and epidemiology of 2019 novel coronavirus: implications for virus origins and receptor binding. Lancet. 2020;395(10224):565.

[55] Huang Y, Yang C, Xu XF, Xu W, Liu SW. Structural and functional properties of SARS-CoV-2 spike protein: potential antivirus drug development for COVID-19. Acta Pharmacol Sin. 2020;41(9):1141.

[56] Xu H, Zhong L, Deng JX, Peng JK, Dan HX, Zeng X, Li TW, Chen QM. High expression of ACE2 receptor of 2019-nCoV on the epithelial cells of oral mucosa. Int J Oral Sci. 2020; 12(1):8.

[57] Holmes EC, Goldstein SA, Rasmussen AL, Robertson DL, Crits-Christoph A, Wertheim JO, Anthony SJ, Barclay WS, Boni MF, Doherty PC, Farrar J, Geoghegan JL, Jiang X, Leibowitz JL, Neil SJD, Skern T, Weiss SR, Worobey M, Andersen KG, Garry RF, Rambaut A. The origins of SARS-CoV-2: a critical review. Cell. 2021;184(19):4848.

[58] Zhao Y, Zhao ZX, Wang YJ, Zhou YQ, Ma Y, Zuo W. Single-cell RNA expression profiling of ACE2, the receptor of SARS-CoV-2. Am J Respir Crit Care Med. 2020;202(5):756.

[59] Hoffmann M, Kleine-Weber H, Schroeder S, Kruger N, Herrler T, Erichsen S, Schiergens T, Herrler G, Wu NH, Nitsche A, Muller MA, Drosten C, Pohlmann S. SARS-CoV-2 cell entry depends on ACE2 and TMPRSS2 and is blocked by a clinically proven protease inhibitor. Cell. 2020;181(2):271.

[60] Duan LW, Zheng QQ, Zhang HX, Niu YN, Lou YW, Wang H. The SARS-CoV-2 spike glycoprotein biosynthesis, structure, function, and antigenicity: implications for the design of spike-based vaccine immunogens. Front Immunol. 2020; 11(2593):576622.

[61] Ou XY, Liu Y, Lei XB, Li P, Mi D, Ren LL, Guo L, Guo RX, Chen T, Hu JX, Xiang ZC, Mu ZX, Chen X, Chen JY, Hu KP, Jin Q, Wang JW, Qian Z. Characterization of spike glycoprotein of SARS-CoV-2 on virus entry and its immune cross-reactivity with SARS-CoV. Nat Commun. 2020;11(1):1620.

[62] Xu Z, Shi L, Wang YJ, Zhang JY, Huang L, Zhang C, Liu SH, Zhao P, Liu HX, Zhu L, Tai YH, Bai CQ, Gao TT, Song JW, Xia P, Dong JH, Zhao JM, Wang FS. Pathological findings of COVID-19 associated with acute respiratory distress syndrome. Lancet Respir Med. 2020;8(4):420.

[63] Mehranfar A, Izadyar M. Theoretical design of functionalized gold nanoparticles as antiviral agents against severe acute respiratory syndrome coronavirus 2 (SARS-CoV-2). J Phys Chem Lett. 2020;11(24):10284.

[64] Tay MZ, Poh CM, Renia L, MacAry PA, Ng LFP. The trinity of COVID-19: immunity, inflammation and intervention. Nat Rev Immunol. 2020;20(6):363.

[65] Vabret N, Britton GJ, Gruber C, Hegde S, Kim J, Kuksin M, Levantovsky R, Malle L, Moreira A, Park MD, Pia L, Risson E, Saffern M, Salome B, Esai Selvan M, Spindler MP, Tan J, van der Heide V, Gregory JK, Alexandropoulos K, Bhardwaj N, Brown BD, Greenbaum B, Gumus ZH, Homann D, Horowitz A, Kamphorst AO, Curotto de Lafaille MA, Mehandru S, Merad M, Samstein RM. Sinai immunology review project immunology of COVID-19: current state of the science. Immunity. 2020;52(6):910. 
[66] Zheng MJ, Gao Y, Wang G, Song GB, Liu SY, Sun DD, Xu YH, Tian ZG. Functional exhaustion of antiviral lymphocytes in COVID-19 patients. Cell Mol Immunol. 2020;17(5):533.

[67] Ju B, Zhang Q, Ge JW, Wang RK, Sun J, Ge XY, Yu JZ, Shan SS, Zhou B, Song S, Tang X, Yu JF, Lan J, Yuan J, Wang HY, Zhao JJ, Zhang SY, Wang YC, Shi XL, Liu L, Zhao JC, Wang $X Q$, Zhang Z, Zhang LQ. Human neutralizing antibodies elicited by SARS-CoV-2 infection. Nature. 2020;584(7819):115.

[68] Rothan HA, Stone S, Natekar J, Kumari P, Arora K, Kumar M. The FDA-approved gold drug auranofin inhibits novel coronavirus (SARS-COV-2) replication and attenuates inflammation in human cells. Virology. 2020;547:7.

[69] Bernstein LR, Zhang L. Gallium maltolate has in vitro antiviral activity against SARS-CoV-2 and is a potential treatment for COVID-19. Antivir Chem Chemother. 2020;28: 2040206620983780

[70] Shu T, Huang MH, Wu D, Ren YJ, Zhang XY, Han Y, Mu JF, Wang RB, Qiu Y, Zhang DY, Zhou X. SARS-coronavirus-2 Nsp13 possesses NTPase and RNA helicase activities that can be inhibited by bismuth salts. Virol Sin. 2020;35(3):321.

[71] Yuan S, Wang R, Chan JF, Zhang AJ, Cheng T, Chik KK, Ye ZW, Wang S, Lee AC, Jin L, Li H, Jin DY, Yuen KY, Sun H. Metallodrug ranitidine bismuth citrate suppresses SARS-CoV-2 replication and relieves virus-associated pneumonia in Syrian hamsters. Nat Microbiol. 2020;5(11):1439.

[72] Iotti S, Wolf F, Mazur A, Maier JA. The COVID-19 pandemic: is there a role for magnesium? Hypotheses and perspectives. Magnes Res. 2020;33(2):21.

[73] Akhtar S, Das JK, Ismail T, Wahid M, Saeed W, Bhutta ZA. Nutritional perspectives for the prevention and mitigation of COVID-19. Nutr Rev. 2021;79(3):289.

[74] Wessels I, Maywald M, Rink L. Zinc as a gatekeeper of immune function. Nutrients. 2017;9(12):1286.

[75] Haase H, Rink L. Multiple impacts of zinc on immune function. Metallomics. 2014;6(7):1175.

[76] Mayor-Ibarguren A, Busca-Arenzana C, Robles-Marhuenda A. A hypothesis for the possible role of zinc in the immunological pathways related to COVID-19 infection. Front Immunol. 2020;11:1736.

[77] Pal A, Squitti R, Picozza M, Pawar A, Rongioletti M, Dutta AK, Sahoo S, Goswami K, Sharma P, Prasad R. Zinc and COVID-19: basis of current clinical trials. Biol Trace Elem Res. 2020;199(8):2882.

[78] Rahman MT, Idid SZ. Can Zn be a critical element in COVID-19 treatment? Biol Trace Elem Res. 2021;199(2):550.

[79] Finzi E. Treatment of SARS-CoV-2 with high dose oral zinc salts: a report on four patients. Int J Infect Dis. 2020;99:307.

[80] Finzi E, Harrington A. Zinc treatment of outpatient COVID-19: a retrospective review of 28 consecutive patients. J Med Virol. 2021;93(5):2588.

[81] Liu QY, Zhao XL, Ma J, Mu YS, Wang Y, Yang SH, Wu YH, Wu FC, Zhou YZ. Selenium (Se) plays a key role in the biological effects of some viruses: implications for COVID-19. Environ Res. 2021;196:110984.

[82] Zhang JS, Taylor EW, Bennett K, Saad R, Rayman MP. Association between regional selenium status and reported outcome of COVID-19 cases in China. Am J Clin Nutr. 2020; 111(6): 1297

[83] Majeed M, Nagabhushanam K, Gowda S, Mundkur L. An exploratory study of selenium status in healthy individuals and in patients with COVID-19 in a south Indian population: the case for adequate selenium status. Nutrition. 2021;82:111053.

[84] Seale LA, Torres DJ, Berry MJ, Pitts MW. A role for selenium-dependent GPX1 in SARS-CoV-2 virulence. Am J Clin Nutr. 2020;112(2):447.
[85] Zhang J, Saad R, Taylor EW, Rayman MP. Selenium and selenoproteins in viral infection with potential relevance to COVID-19. Redox Biol. 2020;37:101715.

[86] Bae M, Kim H. Mini-review on the roles of vitamin C, vitamin $\mathrm{D}$, and selenium in the immune system against COVID-19. Molecules. 2020;25(22):5346.

[87] Youn HS, Lim HJ, Choi YJ, Lee JY, Lee MY, Ryu JH. Selenium suppresses the activation of transcription factor NF-kappa $\mathrm{B}$ and IRF3 induced by TLR3 or TLR4 agonists. Int Immunopharmacol. 2008;8(3):495.

[88] Sugimoto J, Romani AM, Valentin Torres AM, Luciano AA, Ramirez CM, Kitchen N, Funderburg N, Mesiano S, Bernstein HB. Magnesium decreases inflammatory cytokine production: a novel innate immunomodulatory mechanism. J Immunol. 2012;188(12):6338

[89] Tan CW, Ho LP, Kalimuddin S, Cherng BPZ, Teh YE, Thien Y, Wong HM, Tern PJW, Chandran M, Chay WM, Nagarajan C, Sultana R, Low JGH, Ng HJ. Cohort study to evaluate the effect of vitamin D, magnesium, and vitamin B12 in combination on progression to severe outcomes in older patients with coronavirus (COVID-19). Nutrition. 2020;79-80:111017.

[90] Shah A, Frost JN, Aaron L, Donovan K, Drakesmith H, Collaborators. Systemic hypoferremia and severity of hypoxemic respiratory failure in COVID-19. Crit Care. 2020;24(1):320.

[91] Banchini F, Cattaneo GM, Capelli P. Serum ferritin levels in inflammation: a retrospective comparative analysis between COVID-19 and emergency surgical non-COVID-19 patients. World J Emerg Surg. 2021;16(1):9.

[92] Perricone C, Bartoloni E, Bursi R, Cafaro G, Guidelli GM, Shoenfeld Y, Gerli R. COVID-19 as part of the hyperferritinemic syndromes: the role of iron depletion therapy. Immunol Res. 2020;68(4):213.

[93] Dalamaga M, Karampela I, Mantzoros CS. Commentary: could iron chelators prove to be useful as an adjunct to COVID-19 treatment regimens? Metabolism. 2020;108:154260.

[94] Abobaker A. Can iron chelation as an adjunct treatment of COVID-19 improve the clinical outcome? Eur J Clin Pharmacol. 2020;76(11):1619.

[95] Raha S, Mallick R, Basak S, Duttaroy AK. Is copper beneficial for COVID-19 patients? Med Hypotheses. 2020;142:109814.

[96] Rajkumar RP. Lithium as a candidate treatment for COVID-19: promises and pitfalls. Drug Dev Res. 2020;81(7):782.

[97] Das C, Paul SS, Saha A, Singh T, Saha A, Im J, Biswas G. Silver-based nanomaterials as therapeutic agents against coronaviruses: a review. Int J Nanomedicine. 2020;15:9301.

[98] Jeremiah SS, Miyakawa K, Morita T, Yamaoka Y, Ryo A. Potent antiviral effect of silver nanoparticles on SARS-CoV-2. Biochem Biophys Res Commun. 2020;533(1):195.

[99] Abo-Zeid Y, Ismail NSM, McLean R, Hamdy NM. A molecular docking study repurposes FDA approved iron oxide nanoparticles to treat and control COVID-19 infection. Eur J Pharm Sci. 2020;153:105465.

[100] Chuong C, DuChane CM, Webb EM, Rai P, Marano JM, Bernier CM, Merola JS, Weger-Lucarelli J. Noble metal organometallic complexes display antiviral activity against SARS-CoV-2. Viruses. 2021;13(6):980.

[101] Diwaker D, Mishra KP, Ganju L. Potential roles of protein disulphide isomerase in viral infections. Acta Virol. 2013; 57(3):293.

[102] Kieliszek M, Lipinski B. Selenium supplementation in the prevention of coronavirus infections (COVID-19). Med Hypotheses. 2020;143:109878.

[103] Haribabu J, Srividya S, Mahendiran D, Gayathri D, Venkatramu V, Bhuvanesh N, Karvembu R. Synthesis of palladium(II) complexes via michael addition: antiproliferative 
effects through ROS-mediated mitochondrial apoptosis and docking with SARS-CoV-2. Inorg Chem. 2020;59(23):17109.

[104] Pectol DC, DeLaney CR, Zhu JY, Mellott DM, Katzfuss A, Taylor ZW, Meek TD, Darensbourg MY. Dinitrosyl iron complexes (DNICs) as inhibitors of the SARS-CoV-2 main protease. Chem Commun. 2021;57(67):8352.

[105] Morad R, Akbari M, Rezaee P, Koochaki A, Maaza M, Jamshidi Z. First principle simulation of coated hydroxychloroquine on $\mathrm{Ag}, \mathrm{Au}$ and Pt nanoparticles. Sci Rep. 2021;11(1): 2131.

[106] Ali A, Sepay N, Afzal M, Sepay N, Alarifi A, Shahid M, Ahmad M. Molecular designing, crystal structure determination and in silico screening of copper(II) complexes bearing 8-hydroxyquinoline derivatives as anti-COVID-19. Bioorg Chem. 2021;110:104772.

[107] Nikaeen G, Abbaszadeh S, Yousefinejad S. Application of nanomaterials in treatment, anti-infection and detection of coronaviruses. Nanomedicine. 2020;15(15):1501.

[108] Xiao MF, Zeng C, Li SH, Yuan FL. Applications of nanomaterials in COVID-19 pandemic. Rare Met. 2021. https://doi.org/ 10.1007/s12598-021-01789-y.

[109] Liang ZH, Zhu HR, Wang X, Jing B, Li ZF, Xia XY, Sun HW, Yang Y, Zhang WT, Shi L, Zeng H, Sun BB. Adjuvants for coronavirus vaccines. Front Immunol. 2020;11:589833.

[110] Hosseini M, Chin AWH, Behzadinasab S, Poon LLM, Ducker WA. Cupric oxide coating that rapidly reduces infection by SARS-CoV-2 via solids. ACS Appl Mater Interfaces. 2021; 13(5):5919.

[111] Kumar S, Karmacharya M, Joshi SR, Gulenko O, Park J, Kim GH, Cho YK. Photoactive antiviral face mask with self-sterilization and reusability. Nano Lett. 2021;21(1):337.

[112] Kumar A, Sharma A, Chen Y, Jones MM, Vanyo ST, Li C, Visser MB, Mahajan SD, Sharma RK, Swihart MT. Copper@ZIF-8 core-shell nanowires for reusable antimicrobial face masks. Adv Funct Mater. 2020;31(10):2008054.

[113] Aasi A, Aghaei SM, Moore MD, Panchapakesan B. Pt-, Rh-, $\mathrm{Ru}-$, and $\mathrm{Cu}$-single-wall carbon nanotubes are exceptional candidates for design of anti-viral surfaces: a theoretical study. Int J Mol Sci. 2020;21(15):5211.

[114] Bright KR, Sicairos-Ruelas EE, Gundy PM, Gerba CP. Assessment of the antiviral properties of zeolites containing metal ions. Food Environ Virol. 2009;1(1):37.

[115] Wu HQ, Zheng J, Kjoniksen AL, Wang W, Zhang Y, Ma J. Metallogels: availability, applicability, and advanceability. Adv Mater. 2019;31(12):e1806204.

[116] Xing RR, Liu K, Jiao TF, Zhang N, Ma K, Zhang RY, Zou QL, Ma GH, Yan XH. An injectable self-assembling collagen-gold hybrid hydrogel for combinatorial antitumor photothermal/ photodynamic therapy. Adv Mater. 2016;28(19):3669.

[117] Zhang ZZ, He T, Yuan MY, Shen RJ, Deng L, Yi LZ, Sun ZF, Zhang Y. The in situ synthesis of Ag/amino acid biopolymer hydrogels as mouldable wound dressings. Chem Commun. 2015;51(87):15862.

[118] Duygu A, Tuba ED, Nahit A. Synthesis and characterization of novel organo-hydrogel based agar, glycerol and peppermint oil as a natural drug carrier/release material. Mater Sci Eng C. 2020;118:111534.

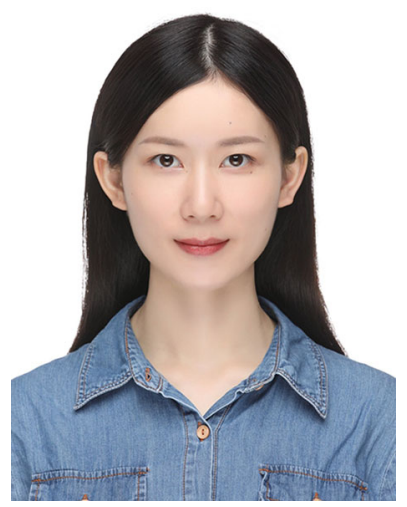

Hui-Qiong Wu obtained her Ph.D. degree in 2019 from the Central South University (CSU), as a coeducated Ph.D. candidate under the supervision of Prof. Yi Zhang at the CSU, Prof. Anna-Lena Kjøniksen at the Østfold University College, and Prof. Wei Wang at the University of Bergen, corporately. Her research interests include the design, synthesis, and application explorations of soft functional materials. She is now working as a postdoctoral researcher at Shenzhen University in collaboration with Institut Jacques Monod, on the study of collective epithelium behavior using bio mimetic soft hydrogels.

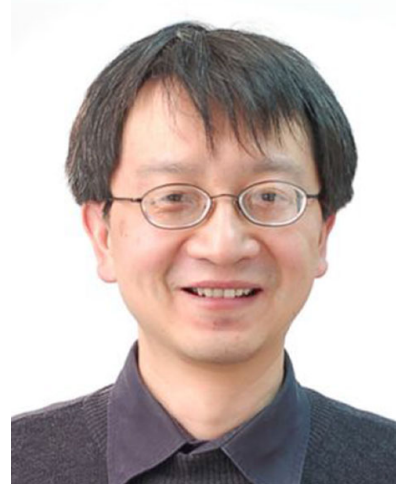

Yi Zhang received his Ph.D. degree from the Institute of Chemistry, Chinese Academy of Science (ICCAS), as a coeducated Ph.D. candidate between the ICCAS and the Max-PlanckInstitute of Colloids and Interfaces. He currently is a full professor in Central South University, Changsha, China. His research interests include the self-assembly behaviors of short peptides, supramolecular hydrogels and aerogels, transition-metal-based sub-nanocatalysts for electrochemical reduction of $\mathrm{CO}_{2}, \mathrm{~N}_{2}$, and energy conversion. He has published over 60 peer-reviewed scientific papers in Nature Communications, Journal of the American Chemical Society, Angewandte Chemie International Edition, Advanced Materials, and other international academic journals. 